\title{
On the Nature of Organs and Organ Systems - A Chapter in the History and Philosophy of Biology
}

\author{
Alessandro Minelli* \\ Department of Biology, University of Padova, Padua, Italy
}

Contrasting definitions of organs based either on function or on strictly morphological criteria are the legacy of a tradition starting with Aristotle. This floating characterization of organs in terms of both form and function extends also to organ systems. The first section of this review outlines the notions of organ and body part as defined, explicitly or implicitly, in representative works of nineteenth century's comparative morphology. The lack of a clear distinction between the two notions led to problems in Owen's approach to the comparative method (definition of homolog vs. nature of the vertebrate archetype) and to a paradoxical formulation, by Anton Dohrn, of the principle of

\section{OPEN ACCESS}

Edited by:

Andreas Wanninger,

University of Vienna, Austria

Reviewed by:

James Richard Griesemer,

University of California, Davis,

United States

Pedro Martinez,

University of Barcelona, Spain

Ignacio Maeso,

Andalusian Center for Development

Biology (CABD), Spain

${ }^{*}$ Correspondence:

Alessandro Minelli

alessandro.minelli@unipd.it

Specialty section:

This article was submitted to Evolutionary Developmental Biology,

a section of the journal

Frontiers in Ecology and Evolution

Received: 22 July 2021 Accepted: 08 November 2021 Published: 03 December 2021

Citation:

Minelli A (2021) On the Nature of Organs and Organ Systems -

A Chapter in the History

and Philosophy of Biology.

Front. Ecol. Evol. 9:745564.

doi: 10.3389/fevo.2021.745564 functional change. Starting from the second half of the twentieth century, with the extensive use of morphological data in phylogenetic analyses, both terms - organ and body part - have been often set aside, to leave room for a comparison between variously characterized attributes (character states) of the taxa to be compared. Throughout the last two centuries, there have been also efforts to characterize organs or body parts in terms of the underlying developmental dynamics, both in the context of classical descriptive embryology and according to models suggested by developmental genetics. Functionally defined organ are occasionally co-extensive with morphologically defined body parts, nevertheless a clear distinction between the former and the latter is a necessary prerequisite to a study of their evolution: this issue is discussed here on the example of the evolution of hermaphroditism and gonad structure and function.

Keywords: organ, body part, organ system, Dohrn, Owen, hermaphroditism, homology, evolutionary morphology

\section{INTRODUCTION}

Five years ago, in a paper published in a medical journal, Coffey and O'Leary (2016) proposed that the mesentery is an organ of the human body and, as such, should be added to the traditional list of human organs, as item No. 79. In a timely review of that article, Neumann (2017) remarked that "no two anatomists are likely to compile identical lists of the organs of the human body," largely because of the vague current notions of organ, "commonly defined in medical dictionaries as a (somewhat independent) part of the body that performs a (vital or special) function."

Despite an admittedly high level of indeterminacy, this tentative definition of organ as a body part with a well-defined function reveals two important features that have accompanied the usage of the term since classical antiquity: on the one side, individual organs are parts of the body; on the other, individual organs perform distinct functions. Sensible (or poorly informative, according to personal preferences) as it may appear, this twofold identity of organs opens a series of questions. First, are there body parts that are not organs? Yes, there are, for example body regions such as head, 
thorax and abdomen, or complex morphological units such as the trunk segments of centipedes. Second, and more interesting, is function, rather than morphology (form, position), the criterion based on which we can (must?) recognize organs?

Russell's (1916) classic monograph on the history of morphology is still a good guide to learn how (or how little) the notion of organ has being changing over the centuries, endlessly oscillating between a functional and a strictly morphological definition, but a look at the original texts is often necessary. In the next section I will thus provide short excerpts from the old literature: for the texts originally in French or German, translation is mine.

As recognized by Haeckel (1866) in his sensible dissection of mid nineteenth century's comparative morphology, this floating characterization of organs in terms of both form and function also extends to the characterization of organ complexes.

We will subsequently see how the lack of a clear distinction between the two notions led to a paradoxical formulation, by Dohrn (1875), of the principle of functional change.

Starting from the second half of the twentieth century, with the extensive use of morphological data in phylogenetic analyses, both terms - organ and body part - have been often set aside, to leave room for a comparison between variously characterized attributes (character states) of the taxa to be compared.

In a number of instances, a functionally defined organ will be co-extensive with a morphologically defined body part, nevertheless a clear distinction between the former and the latter is a necessary prerequisite to a study of their evolution: in a later section of this article, I will discuss this issue on the example of hermaphroditism.

\section{THE DEFINITION OF AN ORGAN}

\section{Organ: Morphological or Functional Concept?}

The primacy of function over morphology seems to be largely accepted. To cite from the introduction (p. 1) to Schmidt-Rhaesa's (2007) book on The Evolution of Organ Systems: "Despite their diversity, all animals have several basic requirements. They have to gather and digest food, get rid of excretes, receive and process information, and so on. The animal body is made up of parts that deal with these requirements and these parts are generally called organs or organ systems."

Eventually, Schmidt-Rhaesa's (2007) catalog of organs includes both items defined by function (e.g., acoustic, balance, cerebral, chordotonal, copulatory, excretory, hydrostatical, phagocytotic, pumping, reproductive, respiratory, sensory, spermatophore-forming, sperm-receiving, and statoacustic organs, plus eyes, gonads, muscles, and ocelli) and items defined by morphology, especially by position (e.g., apical, caudal, intertentacular, nuchal, and ventral organs). This seems to be uncontroversial, but in fact reveals a conceptual interweaving of concepts and definitions originated from within the different disciplines - medicine, natural history and philosophy - that contributed to emergence of biology as the science of the living (e.g., Zammito, 2018; Minelli, 2020).

\section{From Aristotle to Geoffroy Saint-Hilaire}

Russell (1916) defined Aristotle's De Partibus Animalium (cf. Lennox, 2001) as "a comparative organography": the term may suggest attention to the shape of the various organs and their spatial relationships, but Aristotle was interested above all in the function of the different organs.

Two thousand years later, this was still true of the first great comparative anatomists of the French school, both of those in the medical profession (therefore especially knowledgeable and interested in human anatomy), like Félix Vicq-d'Azyr, and of those, like Georges Cuvier, who developed in the natural sciences their whole scientific and academic careers.

Vicq-d'Azyr (1792) opened his long essay on comparative anatomy with a list of the "nine characters or general properties of life; namely: 1 . digestion; 2 . nutrition; 3 . circulation; 4 . breathing; 5. secretions; 6. ossification; 7. generation; 8. irritability; and 9. sensibility." (p. iv). Organs are the tools through which the different functions are performed. The author examined them in the order indicated and for each function he reviewed the various zoological groups (and also plants, occasionally), in order of decreasing complexity of the organs that serve the specific function. But in the following pages Vicq-d'Azyr reversed the perspective, adopting instead a morphological criterion: in his "Table of animals according to the order of their anatomical composition," he recognized twelve groups, from the simplest, such as hydra and other polyps, that have only one organ, the stomach, up to the most complex, i.e., mammals (incl. cetaceans, although listed in the table as a distinct class). And in building an "Essay of physiological classification of the Insects" Vicq-d'Azyr adopted mixed criteria (both the function and the shape of the organs).

Function was also in the foreground in Bichat's (1801, p. lxxix) approach: "All animals are an assemblage of various organs, each performing a function, that contribute, each in its own way, to the conservation of the whole," but the French anatomist also remarked (ibid.) that organs are "themselves formed by several tissues of very different nature, and which truly form the elements of these organs."

Moving at last into zoology as studied by zoologists, the first author to be cited is Cuvier. His position has been well characterized by Remane (1952): "Not even Cuvier managed to accomplish a theoretical distinction between functional and structural units" (p. 22). Indeed, the terms by which he identified body parts have partly functional, partly structural content; see for example the opening sentence of his "Summary idea of the functions and organs of the body of animals, as well as the various degrees of their complication": "After what we have just said of the organic elements of the body, of its chemical principles and of the forces which act in it, we have only to give a summary idea of the detailed functions of which life is composed, and of the organs that are assigned to them" (Cuvier, 1817, p. 36).

Geoffroy Saint-Hilaire's approach to comparative anatomy was very different, in that he tried to find out correspondences between pure morphological units, i.e., body parts. His message 
was clear, despite the frequent differences between his and the current usage of some technical terms. For example, in the Discours préliminaire of his Cours de l'histoire naturelle des Mammifères he stressed the need to exclude the consideration of functions in any philosophical (theoretically acceptable) comparison of organs (Geoffroy Saint-Hilaire, 1828, p. 25).

\section{ORGAN VS. BODY PART}

\section{Owen's Ambiguity: Homolog vs. Archetype}

Reading the works of the comparative anatomists of the early 19 th century is often difficult, not only due to the widespread uncertainty of the meaning attributed to the word "organ" by different authors, and sometimes by the same author on different pages, but also due to the frequent use of technical terms with a different meaning from what the latter have taken in the biology of our times. In the case of Geoffroy Saint-Hilaire, in particular, we must keep in mind that the entities dealt with in his Théorie des analogues (Geoffroy SaintHilaire, 1830) are, in fact, those we call homologs, while Geoffroy's homologues coincide more or less precisely with the body units that Owen (1849) will later describe as serial homologs. For this relationships, such as the one between the fore and hind limbs of a tetrapod, Lankester (1870) will coin the term homoplasy, which is still in use, but with completely different meaning, as structural similarity due to convergence or parallelism (Osborn, 1902, 1905; cf. Toepfer, 2011) and eventually also reversal.

The use of terms such as analogy and homology remained fluctuating, at least up to the famous definitions of Owen (1843), according to which analog is "a part or organ in one animal which has the same function as another part or organ in a different animal" (p. 374) while homolog is "the same organ in different animals under every variety of form and function” (p. 379).

Owen's definition of homolog is the starting point of all subsequent comparative morphology, largely because it seemed to be amenable to reinterpretation in evolutionary terms. Many authors, however, have pointed to an intrinsic weakness in Owen's notion of homology, i.e., the indeterminate nature of that sameness for which it is not easy to imagine an empirical assessment. Actually, in Owen's comparative approach there was another problematic issue, namely the failure to overcome the ambiguity between a morphological and a functional determination of the structures under comparison. In other words, Owen inherited all the uncertainty of previous authors regarding a possible distinction between organ and body part.

The ambiguity is apparent when we pass from the abstract notion of homolog to the archetypal model of the vertebrate endoskeleton that Owen developed in the following years (Owen, $1847,1848,1849)$. This archetype is a series of skeletal segments, osteocommata or vertebrae, each of which is formed in turn, "in its typical completeness," by a specified set of elements and parts. Both in its entirety and in the analytical detail of the parts that compose it, this archetype is not an organ (or an organ system) at all, but a structurally ordered set of body parts.
This archetype lends itself to the most diverse transformations, which involve changes, even radical, of both form and function, as magnificently illustrated in the large plate included in the essay On the Nature of Limbs (Owen, 1849). Owen's archetype is therefore an invariant on the basis of which it is possible to identify homologies - but these are clearly correspondences between body parts (essentially, the parts of the skeleton) based on their mutual topological relationships rather than correspondences between the units traditionally described as organs.

Aware of this ambiguity, Haeckel (1866) observed that there are problems with the traditional classification of body parts into tissues, organs, systems, apparatuses, etc., in that one thinks sometimes more of their morphological, sometimes more of their physiological individuality. Moreover, this terminology has been mostly produced by human anatomists who lack adequate knowledge of the diversity of morphological conditions throughout the animal kingdom.

Important traces of this anthropocentrism are still present in today's comparative anatomy. The catalog of functions recognized in our species and the names of the corresponding organs remain, as far as possible, at the basis of the organography of all animals. Of course, as studies extend to zoological groups further away from vertebrates, the discovery of organs for which it is difficult (sometimes impossible) to suggest a correspondence with an organ in the human body becomes increasingly probable. In some cases it has been found convenient to identify the newly discovered organ by the name of its discoverer, such as the "eyes" of fly larvae, known as Bolwig's organs (described in Bolwig, 1946) and the vomeronasal olfactory organ of many tetrapods, known as Jacobson's organ (named after Jacobson who described it in 1813). Human anatomy has had little need to resort to names of this type, but at least two can be cited, the organ of Corti (1851) and the organ of Zuckerkandl (1901).

\section{The Principle of Function Change}

Nowhere are the dramatic consequences of the missed distinction between organ and body part more evident than in Dohrn's (1875, p. 60) enunciation of the principle of function change (Funktionswechsel):

The organ is remodeled through the succession of functions, the bearer of which remains one and the same organ. Each function is a resultant of several components, one of which is the main or primary function, while the other is an accessory or secondary function. The decrease in the main function and the increase in a secondary function change the overall function; the secondary function gradually becomes the main function, the overall function becomes different, and the consequence of the whole process is the transformation of the organ.

In these words I believe I have expressed a principle, the general validity of which has not yet been adequately appreciated, however, often it may be recognized in individual cases and secretly assumed to be effective. 
The difficulty of enunciating this principle in terms of organ, rather than body part, is evident in Dohrn's words. If organs are anatomical units identified by their functions, how is it possible that an organ whose functions have changed remains the same organ it was before? Dohrn tries go over this riddle by saying that the correspondence between organ and function is not one-toone, but one-to-many. Thus, the identity of the organ is initially ensured by its main or primary function at the moment; after the Funktionswechsel the characterizing function will be another, but this function is not entirely new, because it was part of the complex of functions associated with the same organ before the functional shift. As a formalization of an evolutionary step, this corresponds quite closely to exaptation (Gould and Vrba, 1982) and is therefore reasonable in evolutionary terms. However, in terms of categories applicable to the structure of an organism, Dohrn's effort is perhaps the most paradoxical evidence that missing the distinction between organ and body part can lead to weak or wrong arguments.

\section{Organ Systems}

Shortly after Dohrn proposed his principle of functional change, Gegenbaur (1878, p. 14) summarized the current views on the relationship between structure and function, at last from an evolutionary perspective:

The complication of the organism arises from separation that transfers to individual parts the physiological performance of the originally uniform body. What was previously done by the whole body, individual parts of it do after that process. The function is then either carried out by a larger number of discrete but similar parts, or the individual parts become different from one another. In the first case the division of labor is quantitative, in the latter it is also carried out qualitatively, and the division of the individual parts corresponds to a diversity of the work.

Meanwhile, Haeckel begun to address a further level of complexity that in his Generelle Morphologie der Organismen (General Morphology of Organisms; Haeckel, 1866) corresponds to the highest levels of the structural hierarchy he recognized in the living organisms.

If at the level of what are called organs an ambiguity has dragged on over time with respect to the two possible identification criteria, morphological and functional, can the same be said about organ systems?

According to Haeckel, the hierarchical structure of organisms is the product of two "most essential and supreme laws which guide this union of the simple form individuals [...] into composite ones, [...] the laws of aggregation or community building and of differentiation or division of labor" (p. 289). But the distinction between organ systems and apparatuses is to some extent an arbitrary one, because "In the case of an organ system one has in mind the unity of the form of its essential constituent form-elements, in an apparatus the unity of the performance of these elements" (p. 301); in other terms, "the former is based on a morphological concept, the latter on a physiological concept." "Thus, the term organ system [...] must [...] be used exclusively in its original morphological sense to denote a continuously connected organ complex in which a single tissue, i.e., a single type of cells or cell blocks occurs predominantly as an essential component, as is, e.g., the case with the nervous system, the muscular system, the system of the outer skin layers and their appendages. The situation is different with the expression organ apparatus, which is originally and usually employed in a more physiological sense, to denote a complex of organs (often [...] spatially separated and discontinuous, which only appears to be connected by the common criterion of the same function)" (p. 293). However, "in the concept of the organ apparatus, as it so often occurs in most other such general conceptualizations, physiological and morphological ideas are mixed up in a more or less unclear way and it is therefore difficult to establish satisfactory definitions of these higher organ units" (p. 293). Summing up, Haeckel provided a sensible analysis of the uncertain and to some extent contradictory definitions of structural and functional parts, but failed to provide a valid alternative to an unsatisfactory state of affairs that to some extent is still lasting.

\section{Organs Without Actual Function?}

To determine the importance of the functional criterion in the definition of organ (in particular, the persistence of this association in today's biology), it is worth asking: Are there organs without actual function? In other terms, is it useful (and legitimate) to define an organ in terms of its potential (rather than actual) function? The question is suggested, for instance, by the following remark: "We do not know a single instance of an organ which in the phylogenetic history first appeared as a simple Anlage without subsequent functional stage and only later in phylogeny acquired its functional stage" (Remane, 1952, p. 277). Consider for example the wing imaginal disks of holometabolous insects. It is very difficult to assign them a function in the economy of the larva. Therefore, as long as the insect is in a larval state and the imaginal disk has not yet unfolded into a wing, the imaginal disk should be considered a functionsless body part rather than an organ. A wing disk is a wing in potentiality, but not in actuality. (However, this does not rule out exaptation, as in the case of Drosophila, where the wing disk in the larva secretes an insulin-like peptide that coordinates tissue growth with developmental timing: Colombani et al., 2012; Garelli et al., 2012).

One may be tempted to follow the traditional adultocentric perspective, by saying that function should be best, or exclusively, determined as manifested in the adult, but this would worsen the problem. There are indeed a number of exclusively larval (and even embryonic) organs (think of the apical organ of many invertebrate larvae; Marlow et al., 2014), irrespective of their possible persistence, in modified form, in the adult of some species (as hypothesized, for example, with the possible origin of the frontal sensory organ in adults of the hoplonemertean Quasitetrastemma stimpsoni from the larval apical organ; Magarlamov et al., 2020). In addition, even some of the most basic vital functions, such as feeding, are frequently limited to larval or juvenile stages, as in mayflies and several other insects. 


\section{EVOLUTIONARY MORPHOLOGY}

\section{Organs and Body Parts as Attributes}

In recent decades, the search for homologies and, more generally, comparative biology as a whole (not necessarily limited to morphology) have undergone important developments in the context of phylogenetics. This step was accompanied by the rapid spread of a new language, where terms such as organ or body part appear very rarely. Actually, as rightly observed by Wagner (2014), already in Simpson's (1961) and Mayr's (1969, 1982) historical approach to homology there was no longer trace of organs. Comparisons were proposed instead between attributes of the species under comparison. With the consolidation of phylogenetic systematics, even the term "attribute" disappeared soon: data collected in the matrices used for phylogenetic reconstructions are almost universally described as coded states of characters potentially informative from a phylogenetic perspective. In Sereno's (2007) detailed study (2007) on the Logical basis for morphological characters in phylogenetics, the term "organ" was mentioned only in the line reporting Owen's definition of homology. And the latter is often reformulated today without even mentioning “organ," for example: "homologous features (or states of features) in two or more organisms are those that can be traced back to the same feature (or states) in the common ancestor of those organisms" (Mayr, 1969, p. 85).

Declining interest in descriptive morphology and the common usage in comparative biology (phylogenetics) of "character" for both morphological and molecular units are probably the main reasons for this terminological mix. However, dissecting an animal's body into organs or body parts is not the same as picking convenient characters to fill a morphological data matrix for phylogenetic analysis. The nature of entries in the latter is the most diverse and these entries only occasionally correspond to the organs or body parts of descriptive morphology, less rarely in phylogenetic analyses of phylum- or class-level interrelationships, such as Eernisse et al. (1992), Backeljau (1993), Zrzavý et al. (1998), Brusca and Brusca (2003), Glenner et al. (2004), Schierwater et al. (2009), and Neumann et al. (2021).

As in the case of "organ" in the oldest literature, so the term "character" is used today in different and, very often, not explicitly defined meanings. It is likely, however, that most of the authors who use it, especially among phylogeneticists, would subscribe to Wiley's (1981, p. 8) definition of character as "a feature (attribute, observable part) of an organism" or, better perhaps, "a part or attribute of an organism that may be described, figured, measured, weighed, counted, scored, or otherwise communicated by one biologist to other biologists."

\section{Developmental Perspectives on Organs}

In addition to characterizing organs and/or parts of the body in functional or morphological terms, there have been many attempts to establish their homologies starting from the identity of their primordia, or Anlagen, or the mechanisms by which their morphogenesis unfolds (DiFrisco et al., 2020).

For example, Geoffroy Saint-Hilaire (1807) traced the homologies (analogies, in his terminology) between the bones of the skull of vertebrates based on the identity of the ossification centers from which their formation visibly begins, regardless of whether the anatomical part resulting from each center eventually retains its identity as a separate bone, or merges with neighboring units to form a single bone.

Later, especially under the influence of Haeckel's (1866) views on the relationships between ontogeny and phylogeny, zoologists have often accepted that each organ type derives always from the same embryonic germ layer, thus providing a homology criterion on which to rely even for anatomical comparisons between distantly related animals. Germ layers were discovered in the chicken embryo by Pander (1817), who described them as blastodermal layers (Keimhautblätter). von Baer (1828) regarded them as primitive organs that develop into definitive organs, typically by folding. Remak (1855, pp. 2-3) gave them the name germ layers (Keimblätter) and characterized them in terms of position and function, thus distinguishing an upper, sensory (sensorielles Blatt, Sinnesblatt; p. 86), an intermediate, motor and germinative (motorisch-germinatives Blatt; p. 101) and a lower, trophic germ layer (trophisches Blatt, Darmdrüsenblatt; p. 112). This has been eventually translated into the textbook rough summary: the ectoderm gives rise to the epidermis and the nervous system, the endoderm to the (mid)gut, the mesoderm to the remaining organs. Conserved derivation of specific organs from the same germ layer would support the homology of these organs, in the light of Owens' concept.

But this embryological criterion of homology has not been universally accepted without reservations (e.g., Wilson, 1896), as discussed by Maienschein (1978) and Hall (1995). "Homologous structures need not, and often do not, arise from the same germ layer" (Hall, 1998, p. 171; see also Oppenheimer and Hamburger, 1976); "if there is essentially similar adult structure and relative position the organs are homologous, whether they come from the same or different 'germ layers' .... After all, the different germ layers of a single individual do have the same genes" (Boyden, 1943, p. 239). But different cells, tissues and organs are more or less strictly characterized by different patterns of expression of their genes.

Some recent approaches have suggested that organs may be defined by the locally expressed gene regulatory networks (GRNs). Specifically, Wagner (2014, p. 97) introduced the notion of Character Identity Network, defined as a set of genes whose "main function is to enable the activation of a position specific and organ specific developmental program." More precisely, "The members of the network are jointly necessary for the development of the morphological character, and some of the network members are also individually sufficient to trigger the morphogenesis and differentiation of the character" (Wagner, 2014, p. 118).

However, in a subsequent revisitation, DiFrisco et al. (2020, p. 16) acknowledge that "insisting on a GRN as the basis of character identity in general would not respect the different levels of organization that these anatomical units represent," thus introduce a new conceptual model of Character Identity Mechanisms (ChIMs). This analysis involves a remarkable level of abstraction, that allows "to hypothesize level-specific 'parts' of the ChIM, appropriate for the focal anatomical unit: transcription 
factors for cell types, cell types for tissue types, and signaling centers for organs." (p. 16): ChIMs are intended as "cohesive mechanisms with a recognizable causal profile that allows them to be traced through evolution as homologs despite having a diverse etiological organization. Our model hypothesizes that anatomical units at different levels of organization-cell types, tissues, and organs-have level-specific ChIMs with different conserved parts, activities, and organization." (p. 1).

However, "Some traceable body parts, such as elements of the vertebrate vascular system, may not be endowed with an identifiable ChIM [...] many elements of the vascular system develop from a network of blood vessels that are shaped by epigenetic factors, such as shear stress caused by blood flow and pressure differences. In these cases, an anatomical unit that bears a name and can be compared across divergent lineages does not have a specific ChIM."

\section{Hierarchy Challenged}

The latter sentence signals an interesting step away from a century-long tradition according to which units such as organs, tissues or cells are objectively given and hierarchically ordered kinds for which there must be specific causes.

Rather than representing tiers in a hierarchical organization, cells, tissues, organs or body parts are units of non-necessarily overlapping decompositions. Many tissues, such as blood, are not clearly confined spatially. In the ctenophoran Mnemiopsis leidyi, the patterns recognizable based on transcriptomes disclose a diversity of cell types, most of which cannot be associated with cell types distinguished by morphology or function (Sebé-Pedrós et al., 2018) and well-characterized cell types are recognizable in sponges, despite the lack in those animals of a tissue organization. Other examples are discussed in Minelli (2021).

Organs and body parts are only two of the several kinds of units into which the body has been segmented by morphologists of different times and schools. To put the discussion in full context we should broaden the scope at least to considerations of tissues and cells. However, because of strict limitation to this article's length and of the focus on organs and organ system of the whole Research Topic collection that includes it, this aspect will be simply mentioned here.

Similar to what happens at the level of organ or body part, morphology and function are not always congruent also at the level of cells. Eventually, despite the fact that morphology is usually much more accessible than evidence about function, the first criterion for classification of cell types, at least at the coarsest level (neurons, muscular fibers, secretory cells, etc.) has remained function. We may therefore say that cell types are populations of cells performing different functions (Blainey, 2017; Wagner, 2019). But a satisfactory, exhaustive classification of cell types based on function is often unattainable in practice (Lundberg and Uhlen, 2017; Sanes, 2017).

\section{Position: Tension Between Body Part and Organ}

A fascinating but little investigated aspect of the evolution of animal architecture is the tension between organs and body parts due to non-congruent evolutionary constraints. This happens frequently in miniaturized animals (reviewed in Minelli and Fusco, 2019), especially because of the resistance of the central nervous system to follow the trend in size reduction to which structural units such as segments and body regions (tagmata: head, thorax, abdomen) accommodate more easily. For example, in the larva or the adult, or both, of several miniaturized insects, a part at least of the brain is not hosted within the cephalic capsule, that is, in the head. In the larva of Mikado sp. (Coleoptera Ptiliidae) the brain is shifted to the thoracic segments and in the first instar larva its posterior limit reaches the second abdominal segment. In the first instar larva of Mengenilla chobauti (Strepsiptera) both the brain and the suboesophageal complex are hosted within the thorax and the anterior segments of the abdomen.

\section{A CASE STUDY: THE EVOLUTION OF HERMAPHRODITISM}

If nothing in biology makes sense except in the light of evolution (Dobzhansky, 1973), there is also scope for a study of the evolution of a function or a particular functional state.

If organs are defined in terms of function, while body parts are defined in terms of relative position, organs rather than body parts should be the units about which we will reconstruct a history of evolutionary change. But things are not so simple.

Let's focus on the evolutionary transitions from gonochorism to hermaphroditism and vice versa. For the sake of simplicity, let's ignore here that the term hermaphroditism covers a variety of ways in which sexes can be distributed in a population: very often, all individuals in a population produce both eggs and sperms, either sequentially or simultaneously, but in other species hermaphrodites coexist with unisexuals, more often (in animals) male only (cf. Fusco and Minelli, 2019).

One approach to the evolution of hermaphroditism, perhaps the most popular or most attractive one, is to investigate the contexts in which selection would favor either a transition from gonochorism to hermaphroditism, or the fixation of the latter condition in a more or less large lineage (e.g., Ghiselin, 1969, 1974). However, strictly focusing on the adaptive aspects we would not be able to interpret the distribution of hermaphroditism in the different clades of metazoans, because we would neglect the different constraints caused by the different architecture of the reproductive system in different lineages - that is, by their identity as body parts, rather than as organs.

Examples of the importance of distinguishing between the evolution of hermaphroditism as a function from the evolution of the uni- or bisexual gonads where sperms and eggs are produced are offered by nemerteans (ribbon worms). Most nemerteans are gonochoric, but those that produce both eggs and sperm cells have likely evolved several times independently, judging from the widely different anatomy and topography of their reproductive systems (Hyman, 1951). In ribbon worms generally, there is a row of gonads on each side of the intestine (with a single gonad or a group of gonads between two subsequent diverticula of the gut), but there are exceptions. Some hermaphroditic species have 
separate male and female gonads; others produce both kinds of sex cells in the same gonad; and in Dichonemertes, the anterior gonads are male, the posterior ones are female (Coe, 1938): same functional status (hermaphroditism), but distinct histories of body part evolution.

Hermaphroditism is widespread in crustaceans, but very unequally distributed in the different groups. Cephalocarids and remipeds, all hermaphrodite, have distinct male and female gonads, which occupy distinct segments (Hessler et al., 1995; Kubrakiewicz et al., 2012). Most barnacles, i.e., the members of the Cirripeda Thoracica, are also hermaphrodite (but in several species dwarf functional males also occur, and a few species are gonochoric; Yusa et al., 2013). Here too, male and female gonads are well separate (Gruner, 1993). In the remaining crustacean groups, were hermaphroditism is rare and accidental, or even unknown, eggs and sperms are produced in distinct lobes of the same gonad (e.g., Larsen et al., 2015; Chen et al., 2019; Aneesh and Kappalli, 2020).

Eventually, the evolution of hermaphroditism as a function is not the same as the evolution of the uni- or bisexual gonads involved in the production of sperms and eggs. While functional considerations can explain the presence vs. absence of hermaphroditism in more or less closely related members of a clade, the evolvability of this character (and its actual phylogenetic history) are different in lineages with different body organization, that is, with different gross anatomy - number and distribution of body parts. Hermaphroditism has become the rule in groups where eggs and sperms mature in distinct gonads, but is limited to a small number of species (although, occasionally prevalent in a few lower clades, e.g., the fish families Serranidae and Sparidae) in the groups where male and female germ cells are produced within the same gonad, either simultaneously or in sequence.

\section{CONCLUSION}

Caution in respect to the conceptual or theoretical implications of terminology is of fundamental importance to sort out the mix of categories we have carried with us since the origins of biology,

\section{REFERENCES}

Aneesh, P. T., and Kappalli, S. (2020). Protandrous hermaphroditic reproductive system in the adult phases of Mothocya renardi (Bleeker, 1857) (Cymothoidae: Isopoda: Crustacea) - light and electron microscopy study. Zool. Stud. 59:e61.

Backeljau, T. (1993). Cladistic analysis of metazoan relationships: a reappraisal. Cladistics 9, 167-181. doi: 10.1006/clad.1993.1010

Bichat, X. (1801). Anatomie générale, appliquée à la physiologie et à la médecine. 4 vols. Paris: Brosson, Gabon et Cie.

Blainey, P. (2017). Dynamic cellular personalities. Cell Syst. 4:258. [Part of: Clevers, H., Rafelski, S., Elowitz, M., Klein, A., Shendure, J., Trapnell, C., Lein, E., Lundberg, E., Uhlen, A., Martinez-Arias, A., Sanes, J. R., Blainey, P., Eberwine, J., Kim, J., and Love, J. C. (2017). What is your conceptual definition of "cell type" in the context of a mature organism? Cell. Syst. 4, 255-259. doi: 10.1016/j.cels.2017.03.006],

Bolwig, N. (1946). Senses and sense organs of the anterior end of the house fly larvae. Vidensk. Med. Dansk Naturh. Foren. 109, 81-217. often concealed under polysemic terms derived from ordinary language. However, classic terms of animal morphology such as organ and organ system are probably too rooted in use to expect that they can be replaced by more precisely defined terms.

Complex systems can be decomposed in many different ways, and a choice among the alternatives is not necessarily easy (Levins, 1970; Kauffman, 1971), but this is hardly a disturbing issue from the perspective of the practicing biologist. As noted by Wimsatt (2007, p. 180), "scientists must work with this plurality of incompletely articulated and partially contradictory, partially supplementary theories and models," and different "authors make different conceptual choices in developing their technical concepts all aimed at dealing with the long-recognized fact of nature that morphology and physiology, form and function, are deeply entangled by the development, operation, and evolution of life itself" (Wimsatt, 2007, p. 190).

In a number of instances, a functionally defined organ will be co-extensive with a morphologically defined body part, nevertheless a clear distinction between the former and the latter is a necessary prerequisite to a study of their evolution: the brief discussion on hermaphroditism in the previous section has shown how attention to the categories keeps us away from the risk of collecting under the same heading phenomena or conditions that are comparable only from perspectives other than the one we are currently interested in. For comparative morphologists there is still a lot of work ahead.

\section{AUTHOR CONTRIBUTIONS}

AM is responsible for planning and writing this article.

\section{ACKNOWLEDGMENTS}

I am grateful to Andi Wanninger for inviting me to contribute to this topic collection and to James DiFrisco, Giuseppe Fusco and three reviewers for their precious remarks on previous versions of this article.

Boyden, A. (1943). Homology and analogy: a century after the definitions of "homologue" and "analogue" of Richard Owen. Quart. Rev. Biol. 18, 228-241. doi: $10.1086 / 394676$

Brusca, R. C., and Brusca, G. J. (2003). Invertebrates, 2nd Edn. Sunderland: Sinauer Associates.

Chen, D., Liu, F., Zhu, Z., Lin, Q., Zeng, C., and Ye, H. (2019). Ontogenetic development of gonads and external sexual characters of the protandric simultaneous hermaphrodite peppermint shrimp, Lysmata vittata (Caridea: hippolytidae). PLoS One 14:e0215406. doi: 10.1371/journal.pone.0215406

Coe, W. R. (1938). A new genus and species of Hoplonemertea having differential bipolar sexuality. Zool. Anz. 124, 220-224.

Coffey, J. C., and O'Leary, D. P. (2016). The mesentery: structure, function, and role in disease. Lancet Gastroenterol. Hepatol. 1, 238-247. doi: 10.1016/S24681253(16)30026-7

Colombani, J., Andersen, D. S., and Leopold, P. (2012). Secreted peptide DILP8 coordinates Drosophila tissue growth with developmental timing. Science 336, 582-585. doi: 10.1126/science.1216689 
Corti, A. (1851). Recherches sur l'organe de l'ouïe des mammiferes. Ztschr. Wiss. Zool. 3, 106-169.

Cuvier, G. (1817). Le règne animal distribué d’après son organisation pour servir de base à l'histoire naturelle des animaux et dintroduction à l'anatomie comparée, vol. 1. Paris: Deterville.

DiFrisco, J., Love, A. C., and Wagner, G. P. (2020). Character identity mechanisms: a conceptual model for comparative-mechanistic biology. Biol. Philos. 35:44. doi: $10.1007 /$ s10539-020-09762-2

Dobzhansky, T. (1973). Nothing in biology makes sense except in the light of evolution. Am. Biol. Teach. 35, 125-129. doi: 10.2307/4444260

Dohrn, A. (1875). Der Ursprung der Wirbelthiere und das Princip des Funktionswechsels. Leipzig: Engelmann.

Eernisse, D. J., Albert, J. S., and Anderson, F. E. (1992). Annelida and Arthropoda are not sister taxa: a phylogenetic analysis of spiralian metazoan morphology. Syst. Biol. 41, 305-330. doi: 10.1093/sysbio/41.3.305

Fusco, G., and Minelli, A. (2019). The Biology of Reproduction. Cambridge: Cambridge University Press. doi: 10.1017/9781108758970

Garelli, A., Gontijo, A. M., Miguela, V., Caparros, E., and Dominguez, M. (2012). Imaginal discs secrete insulin-like peptide 8 to mediate plasticity of growth and maturation. Science 336, 579-582. doi: 10.1126/science.1216735

Gegenbaur, C. (1878). Elements of Comparative Anatomy. London: Macmillan \& Co.

Geoffroy Saint-Hilaire, E. (1807). Considérations sur les pièces de la tête osseuse des animaux vertébrés, et particulièrement sur celles du crâne des oiseaux. Ann. Mus. Hist. Nat. 10, 342-365.

Geoffroy Saint-Hilaire, E. (1828). Cours de l'histoire naturelle des Mammifères. Paris: Pichon et Didier.

Geoffroy Saint-Hilaire, E. (1830). Principles de philosophie zoologique discutés en mars 1830, au sein de I'Academie Royale des Sciences. Paris: Pichon et Didier. doi: $10.5962 /$ bhl.title. 2163

Ghiselin, M. T. (1969). The evolution of hermaphroditism among animals. Q. Rev. Biol. 44, 189-208.

Ghiselin, M. T. (1974). The Economy of Nature and the Evolution of Sex. Berkeley: University of California Press.

Glenner, H., Hansen, A. J., Sørensen, M. V., Ronquist, F., Huelsenbeck, J. P., and Willerslev, E. (2004). Bayesian inference of the metazoan phylogeny; a combined molecular and morphological approach. Curr. Biol. 14, 1644-1649. doi: $10.1016 /$ j.cub.2004.09.027

Gould, S. J., and Vrba, E. (1982). Exaptation-a missing term in the science of form. Paleobiology 8, 4-15. doi: 10.1017/S0094837300004310

Gruner, H. E. (1993). "Klasse Crustacea," in Lehrbuch der Speziellen Zoologie, Band I: Wirbellose Tiere, 4. Teil. Arthropoda (begründet von A. Kaestner), ed. H. E. Gruner (Jena: Gustav Fischer), 448-1030.

Haeckel, E. (1866). Generelle Morphologie der Organismen. Allgemeine Grundzüge der organischen Formen-Wissenschaft, mechanisch begründet durch die von Charles Darwin reformirte Descendenz-Theorie. Berlin: Reimer. doi: 10.1515/ 9783110848281

Hall, B. K. (1995). Homology and embryonic development. Evol. Biol. 28, 1-36. doi: 10.1007/978-1-4615-1847-1_1

Hall, B. K. (1998). Germ layers and the germ-layer theory revisited. Primary and secondary germ layers, neural crest as a fourth germ layer, homology, and the demise of the germ-layer theory. Evol. Biol. 30, 121-186. doi: 10.1007/978-14899-1751-5_5

Hessler, R. R., Elofsson, R., and Hessler, A. Y. (1995). Reproductive system of Hutchinsoniella macracantha (Cephalocarida). J. Crust. Biol. 15, 493-522. doi: $10.2307 / 1548771$

Hyman, L. H. (1951). The Invertebrates: Vol. II. Platyhelminthes and Rhynchocoela, the Acoelomate Bilateria. New York: McGraw-Hill.

Kauffman, S. A. (1971). Gene regulation networks: a theory of their global structure and behavior. Curr. Top. Dev. Biol. 6, 145-182. doi: 10.1016/S0070-2153(08) 60640-7

Kubrakiewicz, J., Jaglarz, M. K., Iliffe, T. M., Bilinski, S. M., and Koenemann, S. (2012). Ovary structure and early oogenesis in the remipede, Godzilliognomus frondosus (Crustacea, Remipedia): phylogenetic implications. Zoology 115, 261269. doi: 10.1016/j.zool.2012.01.001

Lankester, E. R. (1870). On the use of the term homology in modern zoology, and the distinction between homogenetic and homoplastic agreements. Ann. Mag. Nat. Hist. 6, 34-43. doi: 10.1080/00222937008696201
Larsen, K., Guţu, M., and Sieg, J. (2015). “Order Tanaidacea Dana," in Treatise on Zoology-Anatomy, Taxonomy, Biology. The Crustacea Revised and Updated, as Well as Extended From the Traité de Zoologie, eds J. C. von Vaupel Klein, M. Charmantier-Daures, and F. R. Schram (Brill: Leiden), 249-329. doi: 10.1163/ 9789004232518007

Lennox, J. G. (2001). Aristotle. On the Parts of Animals I-IV. Translation, Introduction and Commentary. Oxford: Clarendon Press. doi: 10.1093/oseo/ instance.00262098

Levins, R. (1970). "Complex systems," in Towards a Theoretical Biology, Vol. 3, ed. C. H. Waddington (Chicago: Aldine), 73-88. doi: 10.4324/9781315125 893-8

Lundberg, E., and Uhlen, M. (2017). Mapping as a key first step. Cell Syst. 4:257. [Part of: Clevers, H., Rafelski, S., Elowitz, M., Klein, A., Shendure, J., Trapnell, C., Lein, E., Lundberg, E., Uhlen, A., Martinez-Arias, A., Sanes, J. R., Blainey, P., Eberwine, J., Kim, J., and Love, J. C. (2017). What is your conceptual definition of "cell type" in the context of a mature organism? Cell. Syst. 4, 255-259. doi: 10.1016/j.cels.2017.03.006],

Magarlamov, T. Y., Dyachuk, V., and Chernyshev, A. V. (2020). Does the frontal sensory organ in adults of the hoplonemertean Quasitetrastemma stimpsoni originate from the larval apical organ? Front. Zool. 17:2. doi: 10.1186/s12983019-0347-4

Maienschein, J. (1978). Cell lineage, ancestral reminiscence, and the biogenetic law. J. Hist. Biol. 11, 129-158. doi: 10.1007/BF00127773

Marlow, H., Tosches, M. A., Tomer, R., Steinmetz, P. R., Lauri, A., Larsson, T., et al. (2014). Larval body patterning and apical organs are conserved in animal evolution. BMC Biol. 12:7. doi: 10.1186/1741-7007-12-7

Mayr, E. (1982). The Growth of Biological Thought. Diversity, Evolution and Inheritance. Cambridge: Belknap Press of Harvard University Press.

Mayr, W. (1969). Principles of Systematic Zoology. New York: McGraw-Hill.

Minelli, A. (2020). Biology and its disciplinary partitions - intellectual and academic constraints. Sci. Filosofia 24, 105-126.

Minelli, A. (2021). "What's a cell type?," in Origin and Evolution of Metazoan Cell Types, eds S. Leys and A. Hejnol (Boca Raton: CRC Press), 1-11. doi: $10.1201 / \mathrm{b} 21831-1$

Minelli, A., and Fusco, G. (2019). No limits: breaking constraints in arthropod miniaturization. Arthropod. Struct. Dev. 48, 4-11. doi: 10.1016/j.asd.2018. 11.009

Neumann, J. S., Desalle, R., Narechania, A., Schierwater, B., and Tessler, M. (2021). Morphological characters can strongly influence early animal relationships inferred from phylogenomic data sets. Syst. Biol. 70, 360-375. doi: 10.1093/ sysbio/syaa038

Neumann, P. E. (2017). Organ or not? Prolegomenon to organology. Clin. Anat. 30, 288-289. doi: 10.1002/ca.22848

Oppenheimer, J. M., and Hamburger, V. (1976). The non-specificity of the germlayers. Q. Rev. Biol. 51, 96-124. doi: 10.1086/408987

Osborn, H. F. (1902). Homoplasy as a law of latent or potential homology. Am. Nat. 36, 259-271. doi: 10.1086/278118

Osborn, H. F. (1905). The ideas and terms of modern philosophical anatomy. Science 21, 959-961. doi: 10.1126/science.21.547.959-b

Owen, R. (1843). Lectures on the Comparative Anatomy and Physiology of the Invertebrate Animals, Delivered at the Royal College of Surgeons. London: Longman Brown Green and Longmans.

Owen, R. (1847). Report on the archetype and homologies of the vertebrate skeleton. Report Br. Assoc. Adv. Sci. 1846, 169-340. doi: 10.5962/bhl.title. 61890

Owen, R. (1848). On the Archetype and Homologies of the Vertebrate Skeleton. London: John Van Voorst. doi: 10.5962/bhl.title.118611

Owen, R. (1849). On the Nature of Limbs. London: John van Voorst. doi: 10.5962/ bhl.title.50117

Pander, C. H. (1817). Dissertatio inauguralis sistens historiam metamorphoseos, quam ovum incubatum prioribus quinque diebus subit. Wirceburgi: Nitribitt. doi: 10.5962/bhl.title. 48488

Remak, R. (1855). Untersuchungen über die Entwicklung der Wirbeltiere. Berlin: Reimer.

Remane, A. (1952). Die Grundlagen des natürlichen Systems, der vergleichenden Anatomie und der Phylogenetik. Zweite Auflage. Leipzig: Akademische Verlagsgesellschaft Geest and Portig.

Russell, E. S. (1916). Form and Function. London: Murray. 
Sanes, J. R. (2017). Moving forward despite quarrels. Cell Syst. 4:257. [Part of: Clevers, H., Rafelski, S., Elowitz, M., Klein, A., Shendure, J., Trapnell, C., Lein, E., Lundberg, E., Uhlen, A., Martinez-Arias, A., Sanes, J. R., Blainey, P., Eberwine, J., Kim, J., and Love, J. C. (2017). What is your conceptual definition of "cell type" in the context of a mature organism? Cell. Syst. 4, 255-259. doi: 10.1016/j.cels.2017.03.006],

Schierwater, B., Eitel, M., Jakob, W., Osigus, H.-J., Hadrys, H., Dellaporta, S. L., et al. (2009). Concatenated analysis sheds light on early metazoan evolution and fuels a modern "urmetazoon" hypothesis. PLoS Biol. 7:e1000020. doi: 10.1371/ journal.pbio. 1000020

Schmidt-Rhaesa, A. (2007). The Evolution of Organ Systems. Oxford: Oxford University Press. doi: 10.1093/acprof:oso/9780198566687.001.0001

Sebé-Pedrós, A., Chomsky, E., Pang, K., Lara-Astiaso, D., Gaiti, F., Mukamel, Z., et al. (2018). Early metazoan cell type diversity and the evolution of multicellular gene regulation. Nat. Ecol. Evol. 2, 1176-1188. doi: 10.1038/ s41559-018-0575-6

Sereno, P. C. (2007). Logical basis for morphological characters in phylogenetics. Cladistics 23, 565-587. doi: 10.1111/j.1096-0031.2007.00161.x

Simpson, G. G. (1961). Principles of Animal Taxonomy. New York: Columbia University Press. doi: 10.7312/simp92414

Toepfer, G. (2011). Historisches Wörterbuch der Biologie. Stuttgart: Metzler. doi: 10.1007/978-3-476-00439-0

Vicq-d’Azyr, F. (1792). Encyclopédie méthodique. Système anatomique. Quadrupèdes. Tome second. Paris: Panckoucke.

von Baer, K. E. (1828). Über Entwicklungsgeschichte der Thiere: Beobachtung und Reflexion, Erster Theil. Königsberg: Bornträger.

Wagner, G. P. (2014). Homology, Genes, and Evolutionary Innovation. Princeton: Princeton University Press. doi: 10.23943/princeton/9780691156460.001.0001

Wagner, G. P. (2019). "Devo-evo of cell types," in Evolutionary Developmental Biology, eds L. Nuno de la Rosa and G. B. Müller (Cham: Springer), 511-528. doi: 10.1007/978-3-319-33038-9_153-1

Wiley, E. O. (1981). Phylogenetics. New York: Wiley.
Wilson, E. B. (1896). The Embryological Criterion of Homology. Woods Hole, MA: Biological Lectures of the Marine Biological Laboratory, 101-124.

Wimsatt, W. (2007). Re-Engineering Philosophy for Limited Beings: Piecewise Approximations to Reality. Cambridge: Harvard University Press.

Yusa, Y., Takemura, M., Sawada, K., and Yamaguchi, S. (2013). Diverse, continuous, and plastic sexual systems in barnacles. Integr. Comp. Biol. 53, 701-712. doi: $10.1093 / \mathrm{icb} / \mathrm{ict} 016$

Zammito, J. H. (2018). The Gestation of German Biology. Philosophy and Physiology from Stahl to Schelling. Chicago: Chicago University Press. doi: 10.7208/ chicago/9780226520827.001.0001

Zrzavý, J., Mihulka, S., Kepka, P., Bezdek, A., and Tietz, D. (1998). Phylogeny of the Metazoa based on morphological and $18 \mathrm{~S}$ ribosomal DNA evidence. Cladistics 14, 249-285. doi: 10.1111/j.1096-0031.1998.tb00338.x

Zuckerkandl, E. (1901). Ueber Nebenorgane des Sympathicus im Retroperitonaealraum des Menschen. Verh. Anat. Ges . 15, 85-107.

Conflict of Interest: The author declares that the research was conducted in the absence of any commercial or financial relationships that could be construed as a potential conflict of interest.

Publisher's Note: All claims expressed in this article are solely those of the authors and do not necessarily represent those of their affiliated organizations, or those of the publisher, the editors and the reviewers. Any product that may be evaluated in this article, or claim that may be made by its manufacturer, is not guaranteed or endorsed by the publisher.

Copyright $\odot 2021$ Minelli. This is an open-access article distributed under the terms of the Creative Commons Attribution License (CC BY). The use, distribution or reproduction in other forums is permitted, provided the original author(s) and the copyright owner(s) are credited and that the original publication in this journal is cited, in accordance with accepted academic practice. No use, distribution or reproduction is permitted which does not comply with these terms. 